\title{
Penggunaan Metode Bermain Peran untuk Pengembangan Emosional Anak Usia Dini dalam Proses Pembelajaran
}

\author{
Poja Okta Sutria Elisa ${ }^{1,(*)}$, Nur Hazizah \\ ${ }^{1}$ Jurusan Pendidikan Guru Pendidikan Anak Usia Dini, Fakultas Ilmu Pendidikan, Universitas \\ Negeri Padang, Padang, Indonesia \\ ${ }^{*}$ pojaoktasutria@gmail.com
}

\begin{abstract}
ABSTRAK
Penulisan artikel ini bertujuan untuk mengetahui bagaimana pengaruh penggunaan metode bermain peran dalam pengembangan emosional anak pada proses pembelajaran. Metode yang digunakan oleh pendidik sangat berpengaruh terhadap perkembangan anak. Berbagai macam metode yang dapat digunakan untuk perkembangan anak usia dini, salah satunya yaitu metode bermain peran. Penggunaan metode bermain beran sangat terhadap pengembangan emosional anak, dimana melalui metode bermain peran anak bisa mengungkapkan apa yang dirasakan oleh anak tanpa adanya rasa takut, malu, ataupun tekanan dari pihak lain. Hal ini didukung oleh cara atau strategi yang dilakukan oleh pendidik, dimana pendidik harus memiliki cara yang yang menarik dan menyenangkan dalam menerapkan kegiatan bermain peran, sehingga tercipta pembelajaran yang efektif dan efisien untuk mencapai tujuan pembelajaran yang telah ditetapkan.
\end{abstract}

Kata kunci: metode bermain peran dan emosional.

\section{PENDAHULUAN}

Anak usia dini merupakan seorang anak yang sedang mengalami proses perkembangan yang sangat pesat, yaitu usia anak 0-8 tahun yang disebut dengan "golden age" dimana anak memiliki berbagai karakter yang berbeda-beda yaitu anak bersifat egosentris, unik, imajinatif, rasa ingin tahu yang tinggi, dan sebagainya.

Pada masa golden age ini anak membutuhkan seseorang yang lebih tua darinya dalam masa perkembangannya, sehingga anak dapat berkembang sesuai dengan sebagaimana semestinya dan sesuai dengan tingkat usia perkembangannya. Orang yang lebih tua disini yang dimaksud yaitu orang dewasa, orangtua dan gurunya disekolah yang berperan mengambil alih dalam memberikan rangsangan untuk perkembangan anak.

Dalam satuan lembaga pendidikan anak usia dini ada beberapa aspek yang harus dikembangkan yaitu aspek agama dan moral, aspek kognitif, aspek bahasa, aspek psikomotoik, aspek sosial emosional, dan aspek seni. Setiap anak akan mengalami semua aspek perkembangan tersebut, namun tidak dalam waktu yang bersamaan, disesuaikan dengan tingkat perkembangan dan usianya.

Semua aspek perkembangan tersebut hendaknya berkembang secara optimal sesuai dengan tingkat perkembangan dan usianya. Jika ada anak yang tidak mengalami perkembangan sesuai dengan tingkat usianya maka anak tersebut akan mengalami 
keterlambatan dalam perkembangan aspek tersebut, disini guru harus memahami tingkat perkembangan anak dan rangsangan yang diberikan kepada anak tersebut sehingga mencapai aspek perkembangan yang diharapkan. Untuk itu guru harus memiliki strategi dan metode belajar yang bervariasi dan menarik untuk anak. Salah satunya yaitu pembelajaran yang dapat mengembangan emosional anak yaitu dengan metode bermain peran, dimana anak sangat senang jika bermain maka pembelajaran dapat dilakukan sambil bermain. Bermain peran bagi anak merupakan dunianya dimana anak bisa mengembangkan imajinasinya sesuai dengan karakter tokoh dalam cerita tersebut melalui bimbingan dari guru.

Tujuan dari penulisan artikel ini untuk mengatahui bagaimana pengaruh penggunaan metode bermain peran terhadap pengembangan emosi anak usia dini

\section{KAJIAN TEORI}

Walginto (1994) menyatakan bahwa suatu kondisi yang terjadi karena situasi tertentu. Emosi biasanya terjadi yang berhubungan dengan tingkah laku yang mengarah dengan kondisi tertentu. Tingkah laku tersebut biasanya disertai dengan ekspresi sehingga orang disekitar mengetahui kita sedang mengalami emosi (Triantoro, 2012)

Chaplin (2002) menyatakan emosi adalah sutua kondisi yang terstimulasi dari organisme meliputi perubahan yang disadari, yang sifatnya mendalam, dan terjadi perubahan perilaku. (Triantoro, 2012)

Gohm dan Clore (2002) membagi emosi dari akibatnya ada dua yaitu:

a. Emosi positif

Emosi positif yaitu emosi yang memberikan dampak baik atau meyenangkan dan membuat kita nyaman.
Misalnya : senang, gembira, santai, lucu dan sebagainya.

b. Emosi negatif

Emosi negative yaitu emosi yang memberikan dampak tidak menyenangkan dan membuat kita tidak nyaman. Misalnya : kecewa, sedih, depresi, marah dan sebagainya. (Triantoro, 2012)

Beberapa hal yang mempengaruhi variasi emosi pada individu yaitu :

a. Kondisi anak, baik kondisi fisik maupun kondisi psikis sangat menentukan bagaimana emosi yang dimunculkan oleh anak

b. Reaksi sosial, jika anak menerima reaksi sosial yang tidak mengenakan maka reaksi emosi anak jarang terlihat atau tampak.

c. Kondisi lingkungan sekitar anak, dalam hal ini jika anak berada dalam lingkungan yang jenis kelamin sejenis maka akan sering muncul emosi dan lebih mudah

d. Jumlah anggota dalam keluarga, hal ini juga mempengaruhui bagaimana emosi anak, jika anak berada dalam jumlah anggota keluarga yang banyak maka anak akan mudah mengeluarkan emosi.

e. Pola asuh orangtua, anak dengan pola asuh yang otoriter lebih cendrung mendorong emosi cemas dan takut, namum tidak selalu seperti itu tapi kebanyakan.

f. Status sosial ekonomi keluarga, biasanya anak yang status ekonominya renda akan mengembangkan rasa takut jika dibandingkan dengan anak yang status sosialnya tinggi. (Mashar, 2011)

Metode pembelajaran merupakan cara pendidik dan peserta didik dalam 
melakukan proses kegiatan belajar mengajar sehingga tujuan pendidikan tercapai.

Bermain menurut Hurlock (2008) yaitu suatu kegiatan yang dilakukan atas dasar kesenangan tanpa paksaan dari siapapun dan tidak memperhitungkan hasil ahkir. Kegiatan ini dilakukan dengan sukarela dan tidak ada tekanan dari pihak lain. (Hazizah, 2018)

Menurut Mulyasa bermain peran adalah cara siswa dalam menjalin hubungan dengan temannya yang lain melalui cara menirukannya dan membicarakannya sehingga siswa bisa mengembangkan perasaan, nilai-nilai, dan perilaku serta cara penyelesaian masalah. Melalui bermain peran siswa bisa meningkatkan kemampuan kognitif, bahasa, sosial emosional dan mengetahui peran dalam kehidupan bermasyarakat. (Mulyasa, 2009)

\section{Menurut Sofia}

menyatakan bermain peran atau bermain pura-pura adalah memainkan peran tokoh atau benda yang ada didekat anak pada kondisi tertentu sehingga imajinasi anak dapat berkembang melalui kegiatan tersebut.(Bennett, 2014)

Tahapan dalam pembelajaran metode bermain peran menurut Djamarah (2002) yaitu :

a. Guru mengemukakan masalah yang dekat dengan lingkungan anak, sehingga anak tertarik untuk mencari solusinya

b. Memilih peran sesuai dengan masalah yang diangkat tadi, dan guru menjelaskan karakter peran dan apa yang harus dilakukan masing-masing anak

c. Menyusun cara bermain peran sesuai dengan dialog yang disusun oleh guru

d. Siswa yang tidak ikut bermain peran akan menjadi pegamat

e. Siswa melakukan bermain peran sesuai dengan scenario

f. Melakukan evaluasi dengan cara diskusi g. Dan terakhir mengambil kesimpulan (Jumanta, 2014)

Menurut Hartley, Frank, dan Goldenson menyatakan bahwa ada beberapa fungsi bermain yang dapat diterapkan oleh anak saat bermain peran diantaranya :

a. Anak mencontoh kegiatan yang dilakukan oleh orang dewasa, misalnya mencontohkan bagaimana ibunya saat memasak, mencontohkan cara dokter mengobati pasien, dan sebagainya

b. Anak dapat menirukan berbagai kegiatan yang dilakukan di dunia nyata, contohnya cara guru mengajar di sekolah, cara sopir mengendarai mobil, dan sebagainya.

c. Untuk menunjukkan adanya hubungan dalam keluarga dan kejadian yang terjadi di kehidupan nyata, misalnya ibu menyiram bunga, ayah minum teh dipagi hari, dan sebagainya.

d. Untuk menyeluarkan hasrat yang kuat, misalnya memukul-mukul meja

e. Untuk menyeluarkan hasrat yang tidak bisa diterima, seperti berperan sebagai preman

f. Untuk mengulang kembali kegiatan yang biasa dilakukan dirumah, misalnya bangun pagi, mandi, dan sebagainya

g. Memperlihatkan pertumbuhan yang terjadi pada dirinya, seperti anak sudah mampu untuk belari

h. Untuk menyelesaikan masalah, misalnya membersihkan ruangan kelas (Lestari, 2018)

Kelebihan dan kekurangan metode bermain peran. Kelebihan metode bermain peran:

a. Semua siswa bisa ikur serta dan mengembangkan kemampuan sosial emosional anak dalam bermain peran 
b. Siswa bebas mengutarakan apa yang dia rasakan

c. Metode bermain peran bisa dilakukan dalam kondisi dan waktu yang berbeda dengan mudah

d. Guru dengan mudah mengamati perkembangan anak secara utuh saat bermain peran

e. Metode bermain peran merupakan kegiatan yang menyenangkan bagi anak. (Jumanta, 2014) yaitu:

Kelemahan metode bermain peran

a. Anak yang tidak ikut serta bermain peran menjadi kurang aktif dan tidak bisa mengembangkan sosial emosional anak

b. Memerlukan waktu yang cukup banyak

c. Membutuhkan tempat yang luas

d. Kelas yang lain akan merasa terganggu karena suara dari anak yang ikut bemain peran dan suara dari siswa yang jadi pengamat. (Jumanta, 2014)

Manfaat bermain peran bagi anak selain untuk pengembangan emosional anak yaitu :

a) Mengembangkan imajinasi anak, sehingga anak menjadi kreatif dalam melakukan kegiatan bermain peran, misalnya anak menjadi payung sebagai tongkat yang biasa di pakai oleh kakekkakek atau nenek-nenek,

b) Kosakata anak bertambah, biasanya anak hanya meniru kata yang diucapkan oleh orang di sekitarnya saja, melalui kegiatan bermain peran anak menemukan kosakata baru sehingga bahasa anak berkembang.

c) Anak akan menjadi percaya diri, misalnya anak akan merasa senang ketika ia memerenkan peran tokoh polisi, karena ia bangga sudah bisa menjadi seperti peran orang dewasa

d) Motoric anak juga berkembang, dimana saat anak bermain peran anak akan berlarian atau berjalan sesuai dengan karakter yang ia perankan. (Shaleha, 2017)

\section{PEMBAHASAN}

Pembelajaran pada anak usia dini adalah pembelajaran yang menarik dan menyenangkan bagi anak, sehingga anak tertarik untuk mengikuti pembelajaran dan anak ikut berpartisipasi dalam kegiatan yang dilakukan oleh guru di kelas, sehingga tujuan pembelaran tercapai sesuai dengan yang diinginkan. Untuk itu pendidik harus bisa menerapkan metode pembelajaran yang menarik dan menyenangkan untuk diterapkan kepada anak, sehingga anak tidak merasa merasa bosan dan tertarik untuk mengikuti pembelajaran disekolah. Berbagai macam metode yang dapat diterapkan oleh pendidik dalam proses pembelajaran salah satunya yaitu metode bermain untuk mengembangkan sosial emosional anak.

Metode bermain peran merupakan salah satu metode yang digunakan oleh pendidik di lembaga pendidikan anak usia dini dalam proses pembelajaran. Dalam pelaksanaan metode bermain peran anak bisa menyembangkan berbagai aspek perkembangan yaitu, kognitif, bahasa, fisik motorik, sosial emosional, dan seni.

Metode bermain peran dapat meningkatkan kemampuan emosional anak, melalui metode bermain peran anak dapat mengungkapkan apa yang anak rasakan tanpa takut, malu, ataupun tekanan dari siapapun. Contohnya pada saat melakukan metode bermain peran anak bisa menyalurkan emosi yang ada pada dirinya, misalnya saat anak memerankan peran menjadi dokter, anak menjadi senang saat memerankan peran 
dokter karena ia bisa membantu mengobati orang sakit.

Pada saat anak melakukan kegiatan bermain peran dapat melibatkan anak secara emosional seperti melatih sikap simpati anak, rasa sedih, rasa marah, dan sebagainya. Serta dengan bermain peran anak bisa memainkan peran karakter baik, jahat, usil, takut, marah, dan sebagainya dengan sendiri tanpa tekanan dari siapapun. Oleh karena itu, metode bermain peran dapat menjadi suatu cara dalam pengembangan sosial emosional anak usia dini.

Pada saat anak melakukan kegiatan bermain peran, anak melakukan dengan teman yang ada dikelasnya, melalui kegiatan tersebut akan timbul kemampuan untuk berkomunikasi dan berinteraksi, dan kemampuan mengelola emosi pada anak usia dini.

Selain itu metode bermain peran juga bermanfaat untuk aspek perkembangan lainnya yaitu :

a. kepercayaan diri anak akan tumbuh, dengan bermain peran anak akan menjadi percaya diri, seperti saat anak memerankan peran dokter, anak akan merasakan senangnya menjadi dokter yang bisa mengobati orang sakit

b. bahasa anak berkembang, dengan memerankan berbagai peran saat melakukan kegiatan bermian peran, kosakata anak akan bertambah melalui scenario yang disediakan oleh guru.

c. kreativitas anak akan berkembang, melalui bermain peran anak berimajinasi melakukan berbagai hal, misalnya anak menggunakan payung sebagai pistolpistolan dalam kegiatan bermain.

d. dapat memecahkan masalah, pada saat anak bermain peran anak dituntun untuk menyelesaikan masalah yang disajikan dalam scenario yang disediakan oleh guru, dengan anak menyelesaikan masalah maka komunikasi anak dengan temanya yang lain juga tejalin. (Shaleha, 2017).

Peran guru pada saat melakukan kegiatan bermain peran diantaranya :

a. memberikan peluang untuk anak bermain sesuai dengan keinginannya

b. sediakan alat permainan yang dibutuhkan oleh anak untuk bermain

c. pancing anak dengan pertanyaan sehingga anak bisa mengeluarkan ide

d. jika perlu ikut serta dalam kegiatan yang dilakukan oleh anak (Shaleha, 2017)

Guru juga memiliki peran pada saat melakukan kegiatan metode bermain peran yaitu

a) Membiarkan anak untuk bermain, karena anak sangat menyenangi kegiatan bermain melalui kegiatan bermain anak bisa mengembangan berbagai aspek perkembangan

b) Mengamati aspek perkembangan anak

c) Melakukan penilaian terhadap kegiatan yang dilakukan oleh anak, dan memberikan saran apabila ada suatu hal yang kurang tepat

d) Guru memberikan kesimpulan dari hasil kegiatan bermain yang dilakukan oleh anak.

\section{KESIMPULAN}

Penggunaan metode bermain peran dalam proses pembelajaraan sangat berpengaruh terhadap pengembangan emosional anak karena Pada saat anak melakukan kegiatan bermain peran dapat melibatkan anak secara emosional seperti melatih sikap simpati anak, rasa sedih, rasa marah, dan sebagainya. Serta dengan bermain peran anak bisa memainkan peran karakter baik, jahat, usil, takut, marah, dan 
sebagainya dengan sendiri tanpa tekanan dari siapapun.

Pada saat menggunakan metode bermain peran dalam proses pembelajaran guru harus menggunakan cara yang menarik, dan menggunakan scenario yang menarik untuk anak, sehingga anak senang melakukan kegiatan bermain tersebut. Serta guru juga membuat cerita atau scenario yang dekat lingkungan anak, sehingga anak dengan mudah menirukan hal tersebut dan perannya lebih nyata di kehidupan anak tersebut.

Jadi guru harus memiliki berbagai cara atau strategi dalam mengembangan emosional anak, cara atau strategi yang digunakan haruslah menarik perhatian anak dan menyenangkan bagi anak. Pada saat menerapkan hal tersebut guru harus mendampingi atau mengawasi anak.

\section{DAFTAR PUSTAKA}

Bennett, D. M. (2014). PENGEMBANGAN KEMAMPUAN EMOSIONAL MELALUI METODE BERMAIN PERAN PADA ANAK KELOMPOK B TAMAN KANAK- KANAK PERTIWI MLESE II CAWAS KLATEN TAHUN AJARAN 2013/2014. British Journal of Psychiatry, 205(01), 76-77. https://doi.org/10.1192/bjp.205.1.76a

Hazizah, N. (2018). The Importance of Playing for Developing Intelligence in Early Childhood, 169(Icece 2017), 213215.

Jumanta. (2014). Model dan Metode Pembelajaran Kreatif dan Berkarakter. Bogor: Penerbit Ghalia Indonesia.

Lestari, P. (2018). EVEKTIFITAS METODE BERMAIN PERAN DALAM MENGEMBANGKAN KETERAMPILAN SOSIAL ANAK USIA 5-6 TAHUN TAMAN KANAKKANAK ASSALAM 2 SUKARAME BANDAR LAMPUNG.
Mashar, R. (2011). Emosi Anak Usia Dini dan Strategi Pengembangannya. Jakarta: KENCANA.

Mulyasa. (2009). Manajemen Berbasis Sekolah. Jakarta: PT Remaja Rosdakarya.

Shaleha, K. (2017). PERANAN METODE BERMAIN PERAN DALAM MENGEMBANGKAN SOSIAL, 113117.

Triantoro. (2012). Manajemen Emosi. Jakarta: PT Bumi Aksara. 